\title{
Riwayat Pemberian ASI Eksklusif, Asupan Zat Gizi Makro, Riwayat Penyakit Infeksi pada Status Gizi Bayi 6-11 bulan di Desa Kadudampit
}

\author{
Asri Nuraldimas ${ }^{1}$, Rachmanida Nuzrina $^{1}$, Idrus Jusat ${ }^{1}$, Vitria Melani ${ }^{1}$, Lintang Purwara Dewanti ${ }^{1}$ \\ ${ }^{1}$ Prodi Gizi, Universitas Esa Unggul \\ korespondensi e-mail: rachmanida.nuzrina@esaunggul.ac.id
}

Submitted: 12 Oktober 2020, Revised: 26 April 2021, Accepted: 1 Mei 2021

\begin{abstract}
Nutritional status determines the growth and development of babies both physically and cognitive. The high problem of nutritional status in infants and toddlers in Indonesia may increase public bealth problem. The aim of this study was to investigate the relationship bertween exclusive breastfeeding history, macronutrient consumption, and infectious diseases history among babies 6-11 months in Kadudamput Village, Saketi Public Health Center. This research used cross-sectional study design. The total samples were 48 infants. The prevalence of malnutrition was $20.8 \%$. Statistical analysis showed that there were no significant difference between bistory of illness, history of exclusive breastfeeding, and macro-nutrient intake (carbobydrates, protein, fat) based on nutritional status. Health education beyond nutrition and adolescent girls empowerment should be given to prevent the incidence of malnutrition in Kadudampit Village.
\end{abstract}

Keyword: nutritional status, exclusive breastfeeding, macronutrient consumption, and infectious diseases

\begin{abstract}
Abstrak
Status gizi menentukan tumbuh kembang bayi baik secara fisik maupun kognitif. Tingginya masalah status gizi pada bayi di Indonesia meningkatkan masalah kesehatan masyarakat. Tujuan penelitian ini adalah untuk mengetahui hubungan riwayat pemberian ASI eksklusif, asupan zat gizi makro, riwayat penyakit infeksi dengan status gizi bayi 611 bulan di Desa Kadudampit, wilayah Kerja Puskesmas Saketi. Penelitian ini menggunakan design cross-sectional. Total sampel sebanyak 48 bayi. Prevalensi malnutrisi sebsar 20.8\%. Analisis statistic menunjukkan bahwa tidak ada perbedaan signifikan antar asupan zat gizi makro berdasarkan status gizi. Pendidikan kesehatan di luar gizi serta pemberdayaan remaja putri perlu diupayakan untuk mencegah kejadian malnutrisi di Desa Kadudampit.

Kata kunci :Asi eksklusif, status gizi, riwayat penyakit infeksi
\end{abstract}

Kata Kunci: nutritional status, exclusive breastfeeding, macronutrient consumption, and infectious diseases

\section{Pendahuluan}

Status gizi merupakan salah satu tolak ukur untuk menilai perkembangan kesehatan bayi. Penilaian status gizi pada bayi dapat diukur dengan beberapa metode salah satunya adalah pengukuran dengan menggunakan metode antropometri, dalam antropometri dikenal indeks antropometri yang merupakan kombinasi antara beberapa parameter yaitu berat badan sesuai umur (BB/U), Panjang badan sesuai umur $(\mathrm{PB} / \mathrm{U})$ dan berat badan sesuai panjang badan (BB/PB) (1). Faktor-faktor yang mempengaruhi asupan makanan ke status gizi bayi adalah pendidikan, pengetahuan gizi, pola asuh, kebiasaan makan, kebersihan makanan daya beli dan penyakit infeksi. Status Gizi bayi erat hubungannya dengan pertumbuhan bayi, oleh karena itu perlu alat ukur untuk mengetahui adanya kekurangan gizi pada bayi. Indikator $(\mathrm{BB} / \mathrm{U})$ berat badan menurut umur, memberikan gambaran tentang status gizi yang sifatnya umum dan tidak spesifik, berat badan merupakan indikator yang dapat dengan mudah cepat dimengerti oleh masyarakat umum, sensitif untuk melihat perubahan status gizi dalam jangka waktu pendek seperti menurunnya nafsu makan akibat sakit atau karena menderita diare (2).

Masalah gizi merupakan salah satu masalah yang belum terselesaikan di Indonesia termasuk di provinsi Banten. Status gizi bayi 0-23 bulan di Provinsi Banten pada tahun 2016 berdasarkan indeks berat badan menurut umur $\mathrm{BB} / \mathrm{U}$ menunjukkan data bahwa prevalensi gizi buruk $3,2 \%$, gizi kurang $10,1 \%$, gizi baik $84,7 \%$ dan gizi lebih 1,9\%. Milenium Develompent Goals (MDGs) juga menyebutkan bahwa perlu dilakukan perbaikan gizi masyarakat (3). Memasuki usia 6 bulan keatas WHO merekomendasikan 
pemberian makanan pendamping ASI, dengan frekuensi makan 2 sampai 3 kali sehari diusia 6 sampai 8 bulan, meningkat menjadi 3 sampai 4 kali sehari, dilanjutkan 9 sampai 12 bulan dan 12-24 bulan dengan tambahan makanan selingan atau tambahan makanan ringan (snacks) bergizi (seperti sepotong buah atau roti) yang ditawarkan 1-2 kali per hari, sesuai yang diinginkan, sedangkan untuk anak yang tidak lagi menyusui diperlukan frekuensi makan yang lebih sering. Pemberian makanan pendamping ASI (MPASI) sejak dini sebelum usia enam bulan akan menyebabkan bayi rentan mengalami penyakit infeksi dan alergi, sehingga dapat mengakibatkan gizi buruk, dan gangguan pertumbuhan. Frekuensi MPASI makan anak harus sesering mungkin karena anak dapat mengkonsumsi makanan sedikit demi sedikit sedangkan kebutuhan asupan kalori dan zat gizi lainnya harus terpenuhi (4).

Data dari profil kesehatan di Provinsi Banten pada tahun 2016 menunjukkan cakupan pemberian ASI eksklusif 0-6 bulan sebesar 44,1\%, dan pemberian ASI Eksklusif sampai 6 bulan sebesar 35,8\% (5). Data dari puskesmas Saketi menunjukan cakupan pemberian ASI eksklusif 56,89\%, dan bayi yang tidak mendapatkan ASI eksklusif sebesar 43,11\%. Walaupun terjadi peningkatan dibandingkan tahun 2008 yang hanya $28,6 \%$ tetapi berdasarkan data secara nasional itu sangat rendah dari status pencapaian tujuan menuju target Millenium Development Goals (MDGs) pada tahun 2014 sebesar 100\% terkait pengurangan prevalensi kekurangan gizi tahun 2010-2014, bayi 0-6 bulan yang diberikan ASI eksklusif pada tahun 2010 ditargetkan sebesar 65\% dan tahun 2011 sebesar $67 \%$ kemudian menjadi $100 \%$ untuk tahun 2014 (6).

Salah satu faktor yang mempengaruhi tumbuh kembang pada bayi adalah dari asupan gizi terutama pemberian ASI Eksklusif. Telah diketahui bahwa sampai usia 6 bulan, air susu ibu (ASI) adalah makanan yang ideal untuk bayi baik ditinjau dari segi kesehatan fisik maupun psikis. Dengan memberikan ASI Eksklusif sampai bayi berusia 6 bulan akan menjamin tercapainya pengembangan potensi kecerdasan anak secara optimal. ASI selain sebagai gizi seimbang, komposisi yang tepat, serta disesuaikan dengan kebutuhan bayi, ASI juga mengandung gizi khusus seperti taurin, laktosa, AA, DHA, omega 3, omega 6, kolin, dan triptofan yang diperlukan otak bayi agar tumbuh optimal (7). Manfaat pemberian ASI Eksklusif akan terlihat secara signifikan pada saat anak memasuki usia balita. Zat anti infeksi yang terkandung dalam ASI eksklusif akan memberikan perlindungan optimal kepada anak bayi, sehingga resiko untuk terkena penyakit infeksi menjadi berkurang. Pada bayi yang mempunyai riwayat infeksi seperti ISPA dan pneumonia berisiko mempunyai status gizi yang kurang baik (8). Sejauh ini belum ada data mengenai faktor-faktor gizi yang dihubungkan dengan status gizi pada balita di Kabupaten Banten, terutama di desa Kadudampit. Tujuan dari penelitian kami adalah melihat sejauh mana hubungan riwayat pemberian ASI Eksklusif, asupan zat gizi makro dan riwayat penyakit infeksi dengan status gizi pada bayi usia 6-11 bulan di desa Kadudampit Kabupaten Pandeglang Banten.

\section{Metode Penelitian}

Desain penelitian kami adalah cross-sectional study. Penelitian ini dilaksanakan di Desa Kadudampit, Kabupaten Pandeglang Banten. Total sampel dalam penelitian kami sebesar 48 bayi usia 6-11 bulan yang dilaksanakan pada bulan Februari 2020. Variabel yang diukur dalam penelitian kami adalah status gizi, riwayat pemberian ASI, berat badan lahir, status ekonomi, status pekerjaan, pendidikan ibu dan paritas/jumlah anak yang pernah dilahirkan yang diperoleh dari wawancara kuesioner. Sementara untuk antropometri menggunakan digital baby scale dengan tingkat ketelitian $0.1 \mathrm{~kg}$. Setelah data terkumpul, kemudian dianalisis menggunakan analisis univariat dan bivariate dengan menggunakan uji statistic $t$-test. Penelitian ini juga telah mendapatkan persetujuan kode etik penelitian 0105-20.042/DPKE-KEP/FINAL$\mathrm{EA} / \mathrm{UEU} / \mathrm{II} / 2020$

\section{Hasil dan Pembahasan}

Wilayah kerja Puskesmas Saketi terdiri dari 14 Desa dimana yang menjadi lokasi penelitian adalah Desa Kadudampit. Desa Kadudampit yang merupakan desa padat penduduk dimana sesuai hasil sensus penduduk berjumlah 5714 jiwa. Berdasarkan tabel 1, bayi berjenis kelamin laki-laki berjumlah 19 (39,6 \%), dan berjenis kelamin perempuan $29(60,4 \%)$. Bayi yang berusia $6-8$ bulan sebanyak $26(54.16 \%)$ dan yang berusia 9-11 bulan sebanyak 22 (45.83\%). Sebanyak 20.8\% bayi memiliki status gizi kurang, meskipun mayoritas memiliki status gizi normal. Sebanyak 47.9\% memiliki riwayat ASI eksklusif dan 58.3\% memiliki 
riwayat penyakit penyerta. Untuk konsumsi makanan rata - rata konsumsi karbohidrat 85.19 gr $( \pm 1.3)$, protein 23.88 gr ( \pm 1.4 gr) dan lemak 44.92 gr ( \pm 1.4 gr $)$

Tabel 1 Distribusi Karakteristik Bayi

\begin{tabular}{lll}
\hline \multicolumn{1}{c}{ Karakteristik } & N & $\%$ \\
\hline Jenis kelamin & & \\
$\quad$ Laki-laki & 19 & 39,6 \\
$\quad$ Perempuan & 29 & 60,4 \\
\hline Usia (dalam bulan) & & \\
$\quad-8$ & 26 & 14,6 \\
$9-11$ & 22 & 14,6 \\
\hline Riwayat ASI ekslusif & & \\
ASI eksklusif & 23 & 47,9 \\
Tidak ASI Ekslusif & 25 & 52,1 \\
\hline Riwayat Penyakit & & \\
Ya & 28 & 58,3 \\
Tidak & 20 & 41,7 \\
\hline
\end{tabular}

ASI eksklusif adalah pemberian ASI saja sejak bayi dilahirkan sampai usia 6 bulan. Selama itu bayi tidak memperoleh makanan tambahan cairan lain seperti susu formula, air jeruk, air teh, madu, air putih. Pada pemberian ASI eksklusif, bayi juga tidak diberikan makanan tambahan seperti pisang, biskut, bubur nasi, nasi tim dan sebagainya. ASI eksklusif diharapkan dapat diberikan sampai 6 bulan. Pemberian ASI secara benar akan mencukupi kebutuhan bayi sampai usia 6 bulan, tanpa makanan pendamping. Diatas usia 6 bulan, bayi memerlukan makanan tambahan tetapi pemberian ASI dapat dilanjutkan sampai ia berumur 2 tahun (9). Di dalam ASI, terutama saat awal diberikan mengandung kolostrum. Kolostrum merupakan zat kekebalan 10-17 kali lebih banyak dari susu matang (mature). Zat kekebalan yang terdapat pada ASI antara lain akan melindungi bayi dari penyakit mencret (diare). Pada suatu penelitian di Brazil Selatan bayi-bayi yang tidak diberi ASI mempunyai kemungkinan meninggal karena diare 14,2 kali lebih banyak dari pada ASI eksklusif. ASI juga menurunkan kemungkinan bayi terkena penyakit infeksi telinga, batuk, pilek, dan penyakit alergi (9). Bayi ASI eksklusif ternyata akan lebih sehat dan lebih jarang sakit dibandingkan dengan bayi yang tidak mendapat ASI eksklusif. Anak yang sehat tentu lebih berkembang kepandaiannya dibanding anak yang sering sakit terutama bila sakitnya berat (9). Banyak sekali faktor yang mempengaruhi pemberian ASI ekslusif, diantaranya sosial budaya, pengaruh promosi susu formula, dukungan petugas kesehatan, kesehatan ibu, kesehatan bayi, status pekerjaan ibu, tingkat pendidikan ibu dan pengetahuan serta sikap ibu. Pendidikan pada satu sisi mempunyai dampak positif yaitu ibu mengerti akan pentingnya pemeliharaan kesehatan yaitu pemberian ASI ekslusif. Namun demikian, masih ada persepsi di masyarakat bahwa pemberian ASI pada bayi dianggap tidak modern dan menempatkan ibu pada kedudukan lebih rendah dibandingkan dengan ibu golongan atas (10).

Hasil analisi Chi-square menunjukkan bahwa tidak ada hubungan riwayat kesehatan pada status gizi. Hal ini bisa disebabkan karena jumlah sampel yang kurang sehingga kekuatan penelitiannya kurang. Literature menyebutkan bahwa riwayat penyakit berkontribusi pada gizi kurang. Penelitian yang dilakukan Novitasari (2012) menyebutkan bahwa penyakit penyerta berhubungan erat dengan kejadian gizi buruk. Penyakit dapat diartikan sebagai sebuah keadaan dimana terdapat gangguan terhadap bentuk ataupun fungsi salah satu bagian tubuh yang menyebabkan tubuh menjadi tidak dapat bekerja dengan normal (11). Riwayat kesehatan sekarang merupakan data yang berisi keluhan balita sekarang saat pengkajian dilakukan, riwayat kesehatan yang lalu dikaji untuk mengetahui apakah balita mempunyai riwayat penyakit seperti diare, tuber kolosis, HIV/AIDS, penyakit tersebut di atas dapat memperjelek keadaan gizi melalui gangguan masukan makanan dan meningkatnya kehilangan zat-zat gizi esensial tubuh. Bayi yang menderita gizi kurang dan gizi buruk akan mengalami penurunan daya tahan, sehingga rentan terhadap penyakit. Di sisi lain anak yang menderita sakit akan cenderung menderita gizi buruk (12). Penyakit infeksi, sebagai penyebab langsung masalah gizi, keduanya saling berkaitan. Bayi yang tidak mendapat cukup makanan bergizi seimbang memiliki daya tahan yang rendah terhadap penyakit sehingga mudah terserang infeksi. Sebaliknya penyakit infeksi seperti diare dan infeksi saluran pernapasan atas (ISPA) dapat mengakibatkan 
asupan gizi tidak dapat diserap tubuh dengan baik sehingga berakibat gizi buruk. Oleh karena itu, mencegah terjadinya infeksi juga dapat mengurangi kejadian gizi kurang dan gizi buruk.

Analisis asupan makanan juga menyebutkan bahwa tidak ada perbedaan signifikan asupan karbohidrat, protein dan lemak berdasarkan status gizi seperti terlihat pada tabel 2 . Hal ini bisa dikarenakan karena jumlah sampel yang kurang, sehingga tidak begitu terdeteksi dengan analisis statistic. Penemuan ini tentu berbeda dengan literature sebelum-sebelumnya yang menyebutkan bahwa asupan zat gizi makro berhubungan dengan status gizi. Sebagai contoh penelitian Isdaryanti (2007) menyatakan bahwa ada hubungan antara asupan protein pada anak (13). Namun, penelitian lain yang dilakukan Yulni (2013) sejalan dengan hasil penelitian kami dimana tidak adanya hubungan antara asupan protein dengan status gizi menurut umur pada anak di Wilayah Pesisir Kota Makassar (14).

\begin{tabular}{|c|c|c|c|c|}
\hline & & & & \\
\hline \multicolumn{5}{|l|}{ Karbohidrat } \\
\hline Gizi kurang & 84,6 & 1,9 & 0,6 & 0,113 \\
\hline Normal & 85,3 & 1,0 & 0,1 & \\
\hline \multicolumn{5}{|l|}{ Protein } \\
\hline Gizi kurang & 23,6 & 1,9 & 0,6 & 0,605 \\
\hline Normal & 23,9 & 1,2 & 0,2 & \\
\hline \multicolumn{5}{|l|}{ Lemak } \\
\hline Gizi kurang & 44,6 & 1,9 & 0,6 & 0,555 \\
\hline Normal & 45 & 1,3 & 0,2 & \\
\hline
\end{tabular}

Konsumsi lemak juga diketahui menjadi faktor penyumbang dalam membentuk status antropometri anak. Dari hasil recall yang dilakukan didapat gambaran bahwa sumber lemak pada responden sebagian besar berasal dari gorengan tempe dan tahu yang diberikan kepada responden. Konsumsi lemak dari sumber nabati tentu tidak memberikan dampak signifikan bagi pertumbuhan bayi. Asam amino di dalam sumber lemak hewani mengandung asam amino lengkap dan esensial bagi bayi. Selain itu sumber hewani juga menyumbang zat gizi esensial yang diperlukan untuk penyempurnaan fungsi kognitif anak seperti vitamin dan mineral besi. Hasil penelitian kami tidak menunjukkan hasil signifikan dari konsumsi makanan karena menurut data wawancara asupan makanan recall 2x24 jam pola asupan makanan responden yang relative sama. Variasi data yang kurang membuat data penelitian tidak menunjukkan kekuatan statistik yang signifikan.

\section{Kesimpulan}

Tidak ada perbedaan signifikan riwayat penyakit, riwayat asi ekslusif, dan asupan zat gizi makro yaitu karbohidrat, lemak dan protein berdasarkan status gizi balita. Pendidikan kesehatan di luar gizi seperti imunisasi dan perbaikan status kesehatan remaja putri diperlukan untuk mencegah insiden malnutrisi di Desa Kadudampit, Kab. Banten, Jawa Barat.

\section{Ucapan Terimakasih}

Ucapan terimakasih terhadap ibu balita yang berpartisipasi dalam penelitian ini. 



\section{Daftar Pustaka}

1. Wiyono S, \& Harjatmo T-P. Penilaian Status Giži. Jakarta: Indo. Kemkes. BPPSDM; 2019.

2. Wulandari Ika Fitria, Iriana N-R. Karakteristik Ibu Menyusui yang Tidak Memberikan ASI ekslusif di UPT Puskesmas Banyudono Kabupaten Boyolali. J Ilm Rekam Medis dan Inform Kesehat. 2013;3(2):12-24.

3. Kemenkes R. Profil Kesehatan Indonesia 2016. Jakarta: Kementerian Kesehatan Republik Indonesia.; 2017.

4. Widyawati W, Febry F, Destriatania S. Analysis Complementary Feeding and Nutritional Status Among Children Aged 12-24 Months in Puskesmas Lesung Batu, Empat Lawang. J Ilmu Kesehat Masy. 2016;7(2):139-49.

5. Kemenkes R. Profil kesehatan Indonesia. Jakarta: Kementrian Kesehatan Republik Indonesia; 2016.

6. Bappenas B-P. Perencanaan Aksi Nasional Pangan dan Gizi 2011-2015. Jakarta: Mentri Perencanaan Pembangunan Nasional.; 2011.

7. Devriany A, Wardani Z, Yunihar Y. Perbedaan Status Pemberian ASI Eksklusif terbadap Perubahan Panjang Badan Bayi Neonatus. Media Kesehat Masy Indones. 2018;14(1):44.

8. Wahyuni R. Hubungan Faktor Lingkungan dan Faktor Perilaku Keluarga dengan Kejadian ISPA pada Balita di Puskesmas Ambacang Padang Tabun 2010. Univ Andalas. 2011.

9. Maryunani A. Inisiasi Menyusui Dini, Asi Eksklusif Dan Majemen Laktasi. Jakarta: Trans Info Media; 2012.

10. Nilakesuma A, Jurnalis Y-D, Rusjdi S-R. Hubungan Status Gizi Bayi dengan Pemberian ASI Ekslusif, Tingkat Pendidikan Ibu dan Status Ekonomi Keluarga di Wilayah Kerja Puskesmas Padang Pasir. J Kesehat Andalas. 2015;4(1):37-44.

11. Novitasari D. Faktor-Faktor Risiko Kejadian Gizi Buruk Pada Semarang. Fak Kedokt UNDIP. 2012;14-25. Available from: http://eprints.undip.ac.id/37466/1/DEWI_NOVITASARI_A\%2C_G2A008052\%2C_LAPO RAN_KTI.pdf

12. WHO. Pelayanan Kesehatan Anak di Rumah Sakit. Jakarta: WHO Indonesia. 2014.

13. Isdaryanti C. Asupan Energi Protein, Status Giri, dan Prestasi Belajar Anak Sekolah Dasar Arjowinangun 1 Pacitan. Univ Gajah Mada. 2007.

14. Yulni. The Relationship between the Macronutrient Intake and Nutritional Status of Elementary School Children in the Coastal Region of Makassar City. J MKMI, Desember 2013, hal 205-211. 2013. 